UDC: 636.2(497.17)

COBISS.SR-ID: 227893516

Original research paper

Acta Agriculturae Serbica, Vol. XXI, 41 (2016); 17-24

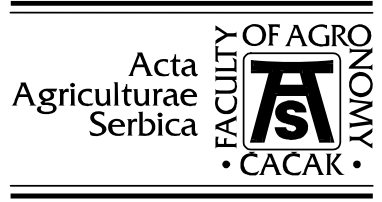

\title{
Conservation of the genetic material of Macedonian Busha cattle
}

\author{
Bunevski Gj. ${ }^{1}$, Jelena Nikitovic ${ }^{2}$, Saltamarski Z. ${ }^{2}$ \\ ${ }^{1}$ Institute of Animal Biotechnology, Faculty of Agricultural Sciences and Food- \\ Skopje, RM, Republic of Macedonia (e-mail: bunevski@gmail.com) \\ ${ }^{2}$ NGO Busha, Skopje
}

\begin{abstract}
The Busha is an indigenous breed of cattle in many Balkan countries. It has been bred for centuries. It belongs to primitive shorthorn cattle (Bos brachyceros europaeus). These cattle used to be the dominant and most important breed in almost all Balkan countries until the 1950s and 1960s, but today in lowland areas where intensive farming is practiced they have already been replaced by more productive and specialized breeds of cattle. In Macedonia this breed has officially been classified as a triple purpose breed (raised for meat, milk and draft) but considering its low production capabilities it is more similar to some primitive draft breeds. This breed is part of the National Biodiversity Program for the conservation of indigenous breeds of animals in the Republic of Macedonia. Economic, cultural and scientific reasons underlie the need to protect the biological diversity of autochthonous breeds of cattle such as the Busha. The aim of the research was to establish a gene bank for different strains of adult Busha cattle in the Republic of Macedonia. To this end, 998 samples of blood, 1100 hair coat samples and 958 doses of semen were collected from adult Busha cattle. Also, a phenotypic characterization was done on adult Busha cattle for their major productive and morphological traits. During the last few years, there have been certain negative trends in the population size of Busha cattle in accordance with the decline of the rural population in the hills and uplands and young people's disinterest in rearing indigenous breeds of cattle such as the Busha.
\end{abstract}

Key words: cattle, Busha, autochthonous breed, gene bank, biodiversity, phenotypic traits.

Received: 14.03.2016; Accepted: 16.11.2016 


\section{Introduction}

Cattle including various breeds, strains and crosses are a main source of milk in Balkan countries. The cattle industry consists of three sectors: small-scale farmers (around 90\%) keeping 1-3 cows and mainly producing for home consumption; medium-scale farmers (5\%) keeping 10-15 cows with an annual production of 4,000-5,000 kg milk/head and specialized commercial farms (around 5\%) with more than 50 head of cattle that produce annually over 7,000 $\mathrm{kg}$ milk intended solely for the market. In the rural mountain regions of Macedonia, the dominant types of cattle are crosses of the Busha breed. This breed of cattle, also known as Illyrian cattle, is an autochthonous breed of the Balkan Peninsula. It has been bred for centuries in this area and belongs to primitive short horn cattle (Bos brachyceros europaeus). In Macedonia, this breed is officially classified as a triple purpose breed (raised for meat, milk and draft) but considering its low production capabilities it is more similar to some primitive draft breeds. The main strength of this breed is that it survives well under minimum levels of management, has low feeding requirements and thrives on natural grazing. These shorthorn cattle used to be the dominant and most important breed in marginalized rural areas of Macedonia, Croatia, Bosnia and Hercegovina, Montenegro, Serbia, Albania, Bulgaria and Greece until the middle of the 20th century and are still crucial in some rural mountainous parts of the Balkans. In the past, several imports of more productive dual-purpose breeds were made in Macedonia to improve the production capabilities of the native Busha cattle. However, this improvement was carried out without proper control and record keeping which in turn resulted in drastic reduction of the number of indigenous Busha animals.

The Busha is an indigenous, actually a trans-boundary breed, which is in high danger of extinction. It used to be the dominant and most important breed in almost all Balkan countries until the 1950s and 1960s but today in lowland areas where intensive farming is practiced this breed has already been replaced by more productive and specialized breeds of cattle. In Macedonia, this breed has officially been classified as a triple purpose breed (raised for meat, milk and draft) but considering its low production capabilities it is more similar to some primitive draft breeds. Today, these cattle are no longer used for work but due to the absence of a systematic cattle improvement program these animals have retained their poor beef and dairy production capabilities. Nevertheless, the Busha genome is very elastic since this breed easily achieves better milk production and bigger body weight under unfavorable conditions. Given the high adaptability of this breed to the very harsh feeding and housing conditions existing in the rural areas of Macedonian mountains and its resistance to diseases, 
the Busha is still the most significant beef and, sometimes, milk resource for these areas where more productive cattle breeds cannot thrive successfully.

In the past several decades, as a result of uncontrolled crossing of this breed with some more productive breeds, the number of purebred Busha animals has permanently decreased, which imposes an urgent need for setting up in situ and ex situ conservation program for this breed. Economic, cultural and scientific reasons underlie the need to protect the biological diversity of autochthonous breeds such as the Busha.

\section{Busha strains in the Republic of Macedonia}

There are two main classifications of Busha strains in the Republic of Macedonia:

a) Classification of strains according to locality:

- Povardarie strain,

- Polog strain,

- Orgazden strain,

- Prespa (Ohrid) strain,

- Mariovo strain, etc.

b) Classification of strains according to color:

- Black strain,

- Brown strain,

- Red strain,

- Gray strain and

- Tiger strain.

In Macedonia, the following varieties classified by their coat color are found: the black Busha, reared in Debar, Tetovo and Gostivar regions (Polog strain); the red Busha (Metohija strain); the gray Busha (Povardarie and Prespa or Ohrid strains); the brown strain (Ograzden strain) and sometimes the so-called "tiger" strain.

\section{Current situation of cattle breeding in the Republic of Macedonia}

According to the official statistical data, there are 238,000 head of cattle in the Republic of Macedonia (FAO, 2014), with Busha cattle accounting for 12,064 or $5.6 \%$ of the total number (Food and Veterinary Agency-FVA, 2014), but in reality, there are approximately 1,000-2,000 head of Busha cattle in the Republic of Macedonia.

\section{State policy and legislation on conservation of Busha cattle}

In 2008, a new Law on Animal Production was adopted in the Republic of Macedonia, with several articles governing biodiversity and species of autochthonous breeds of cattle in Macedonia. The Busha is the only autochthonous breed of cattle in Macedonia. 
In 2010, the Common Livestock Breeding Program was established by the Ministry of Agriculture, Republic of Macedonia for the period 2010-2020, with the main focus given to the Busha breed of cattle. According to this program, a Separate Breeding Program for each species and breed is to be implemented for the duration of 5 years.

In 2011, the Livestock Biodiversity Program was adopted by the Ministry of Agriculture, Republic of Macedonia for the period 2011-2017, with the main activities including:

- Taking inventory,

- Characterization, monitoring of trends and risks

- Phenotype analyses,

- Production traits,

- Reproduction traits,

- DNA characterization, and

- Creating a gene bank of semen, blood and hair.

The overall objective of the National Breeding Program for Busha cattle is to implement the national plan for the conservation and sustainable use of Busha cattle.

Tab. 1 Cattle breed distribution in the Republic of Macedonia according to official data (FVA, 2014)

\begin{tabular}{|c|c|c|c|c|c|c|c|c|}
\hline \multirow[b]{2}{*}{ Breed } & \multicolumn{2}{|c|}{2008} & \multicolumn{2}{|c|}{2010} & \multicolumn{2}{|c|}{2012} & \multicolumn{2}{|c|}{2013} \\
\hline & $\begin{array}{c}\text { No. of } \\
\text { head }\end{array}$ & $\%$ & $\begin{array}{c}\text { No. of } \\
\text { head }\end{array}$ & $\%$ & $\begin{array}{c}\text { No. of } \\
\text { head }\end{array}$ & $\%$ & $\begin{array}{c}\text { No. of } \\
\text { head }\end{array}$ & $\%$ \\
\hline Busha cattle & 29535 & 12.12 & 27242 & 7.80 & 20363 & 10.11 & 12064 & 5.64 \\
\hline Crosses of & & & & & & & & \\
\hline $\begin{array}{l}\text { Busha and } \\
\text { other breeds }\end{array}$ & 89707 & 36.82 & 104961 & 43.56 & 113720 & 38.95 & 98958 & 46.30 \\
\hline $\begin{array}{l}\text { Total No. of } \\
\text { cattle }\end{array}$ & 243667 & 100.0 & 269443 & 100.0 & 261073 & 100.0 & 213747 & 100.0 \\
\hline
\end{tabular}




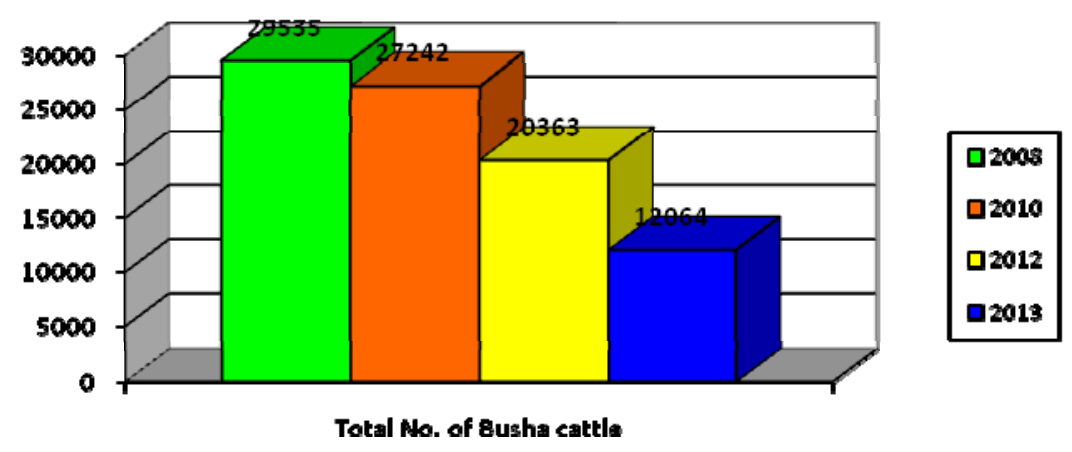

Graph. 1 Total No. of Busha cattle in RM (FVA, 2014)

\section{Material and methods}

After phenotypic characterization and taking inventory of Busha cattle according to the breed standards described in the National Breeding Program for Busha cattle, the second phase was to collect samples of blood, semen and hair from adult Busha male and female cattle for the gene bank owned by the Ministry of Agriculture, Forestry and Water Economy of the Republic of Macedonia.

Several herds of Busha cattle were evaluated for phenotypic traits including the main productive, morphological and reproductive properties. All of them were reared under semi-nomadic system i.e. during winter, from the end of October until mid April, they were kept in rural mountain areas, whereas during the warm part of the year they were moved to mountain pastures to access water sources and pasture. The controlled Busha cattle were mainly used for beef production, but some of them were milked by hand only for farmers' own needs, not for sale. As for dairy production traits, the main emphasis was placed on milk yield per day and milk content (percentage of fats, proteins, solids non-fat and dry matter in milk). The beef production traits studied included average daily gain and body weight at 6 and 12 months of age and meat percentage from the carcass. The main morphological traits were measured with Lydtin's rod and tape measure, only on adult Busha cattle. Also, several main reproductive traits were measured, as follows: age at first mating and delivery, duration of open days and calving period, as well as birth weight and body weight.

The second phase upon data collection for phenotypic characterization of Busha cattle involved collection of biological material in blood, hair and semen samples for the gene bank. Blood samples were taken by a veterinary team from the jugular vein of each animal in special vacuum tubes containing preservatives 
and were frozen at $-40^{\circ} \mathrm{C}$. Hair samples were taken from the withers or tail using special tools for collecting the whole hair together with the root. Thereafter, hair samples were packed in plastic bags and labeled with the animal identification data. Semen was taken under field conditions by the veterinary team using electro-ejaculation of Busha bulls after they had been restrained and stimulated. Upon semen sampling from Busha bulls, the semen was transported in a special container to the veterinary lab for quality assay, and was then packed in $0.45 \mathrm{ml}$ straws and stored at $-196^{\circ} \mathrm{C}$ in vessels containing liquid nitrogen.

\section{Results and Discussion}

As regards tissue sample collection, the focus was placed on blood, hair and semen sampling for the Busha cattle gene bank.
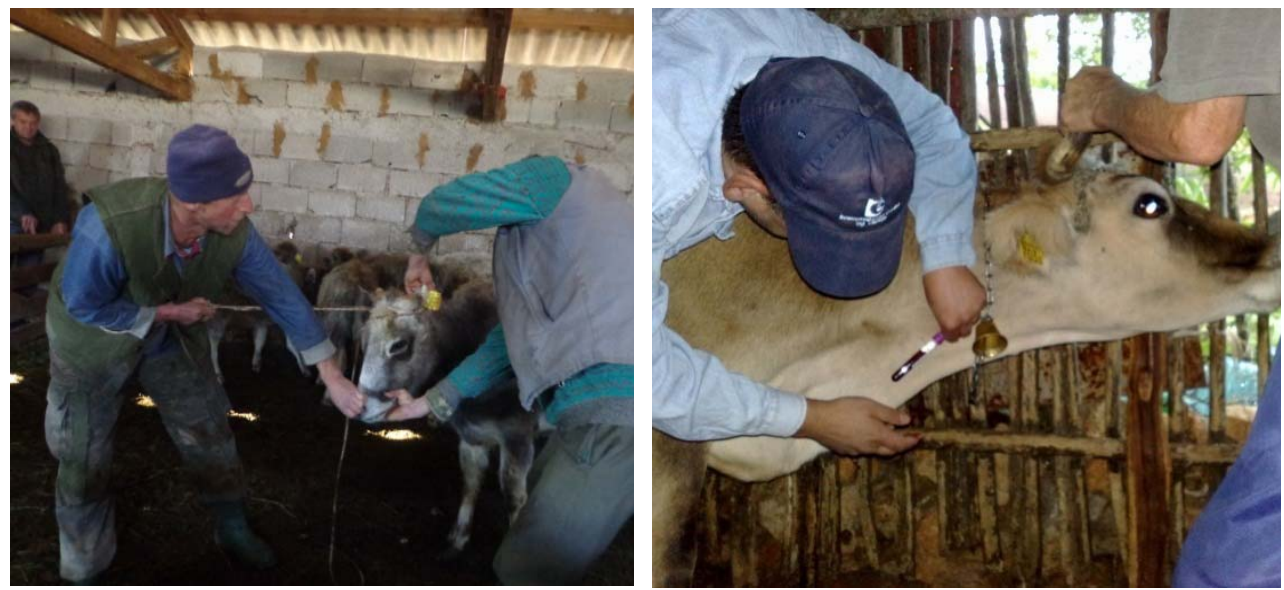

Pictures 1 and 2 Restraining (fixation) and blood sampling of Busha cattle

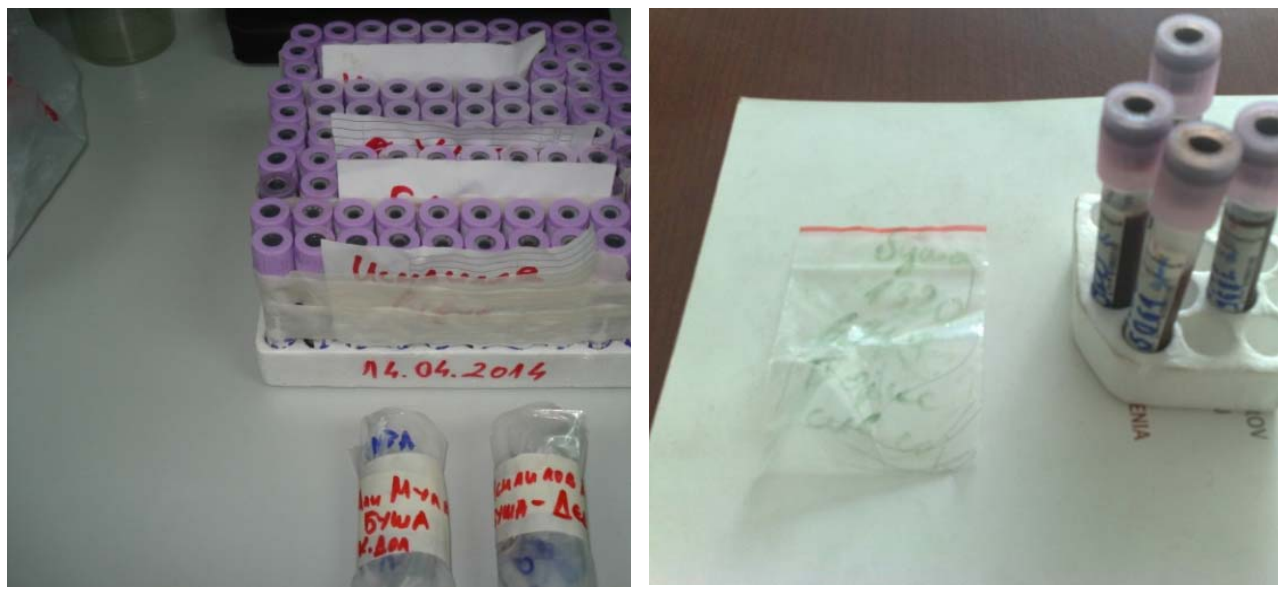

Pictures 3 and 4 Packaging and identification of blood and hair samples of Busha cattle 
Tab. 2 Number of blood, hair and semen samples collected from Busha cattle

\begin{tabular}{cccc}
\hline Parameter & Blood samples & Hair samples & Semen doses \\
\hline Number & 998 & 1100 & 958 \\
\hline
\end{tabular}

All tissue samples including blood, hair and semen samples are stored properly and periodically maintained and tested for quality, and are subject to further analysis i.e. molecular and DNA assays.

\section{Photo documentation of tissue sampling in Busha cattle}

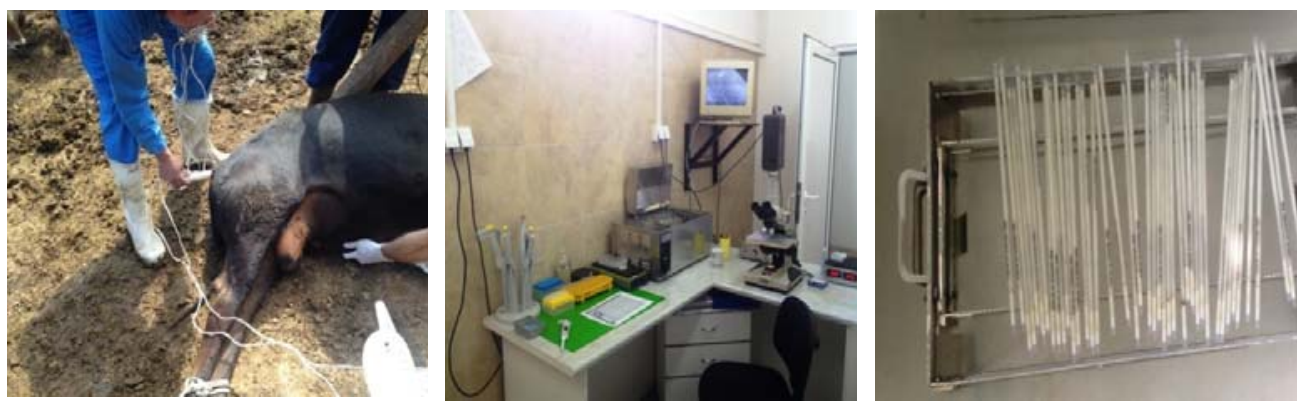

Pictures 5, 6, and 7 Restraining (fixation), electroejaculation, semen collection, testing and packaging of semen in straws from Busha bulls

The collection of data for phenotypic traits and tissue conservation for the gene bank was conducted by a team of experts from 3 Skopje institutions - the Faculty of Agricultural Sciences and Food, the Institute of Animal Production and the Faculty of Veterinary Medicine. All tissue samples collected from the autochthonous cattle breed Busha for the gene bank are owned by the Ministry of Agriculture, Forestry and Water Economy of the Republic of Macedonia.

\section{Conclusion}

The aim of the research was to create a gene bank of tissue samples from the autochthonous cattle breed Busha in the Republic of Macedonia, as well as to estimate the main productive, reproductive and exterior traits through phenotypic characterization. To this end, 998 samples of blood, 1100 hair coat samples and 958 doses of semen were collected from adult Busha cattle. All tissue samples collected from the autochthonous cattle breed Busha are owned by the Ministry of Agriculture, Forestry and Water Economy of the Republic of Macedonia. All tissue samples including blood, hair and semen samples are stored properly and periodically maintained and tested for quality, and are subject to further analysis i.e. molecular and DNA assays. 


\section{References}

Bunevski, Gj. (1994.): Improving of domestic cattle Busha (seminar paper). 1-61, Skopje. Bunevski, Gj., Trajkovski, T., Trifunovic, G., Adamov, M. (2004.): Selection program of cattle in the Republic of Macedonia. $16^{\text {th }}$ Symposium on innovation in animal science and production, Biotechnology in Animal Science. Belgrade.

FAO (2014): Annual statistical review. Roma (http://www.fao.org/home/en/).

Food and Veterinary Agency (FVA) of RM (2014): Cattle breed structure in Macedonia (http://www.fva.gov.mk/index.php?lang=mk).

Ilkovski, R., Trajkovski, T., Bunevski, Gj. (1994.): State and perspective of cattle production in the R.epublic of Macedonia. Meeting Faculty - Farms, Skopje.

Kume Kirstaq, Papa L., Brka M., Dokso A., Zecevic E., Rustempasic Alma, Ivankovic A., Ramljak Jelena, Ligda Christina, Georgoudis A., Bytyqi H., Mehmeti H., Bunevski Gj., Markovic Bozidarka, Markovic M., Stojanovic S., Bogdanovic V., Perisic P. (2013): Busha - old cattle in the Balkans, ERFP project - evaluation of the current status of Busha cattle and development of a regional breeding program for their conservation and sustainable economic use, 1-71.

Trajkovski, T., Bunevski, Gj. (2006.): Cattle breeding. Book, 1-371, Skopje. 